\title{
Effects of prostaglandin administration 10 days apart on reproductive parameters of cyclic dairy nulliparous goats
}

\author{
[Efeitos da aplicação de prostaglandinas intervaladas de 10 dias sobre características reprodutivas de \\ cabras leiteiras nulíparas cíclicas] \\ J.F. Fonseca ${ }^{1}$, V.V. Maffili ${ }^{2}$, A.D.F. Santos ${ }^{2}$, R. Fürst ${ }^{2}$, C.P. Prosperi ${ }^{2}$, H. Rovay ${ }^{2}$, \\ J.M.G. Souza ${ }^{2}$, C.A.A. Torres ${ }^{2}$ \\ ${ }^{1}$ Embrapa Caprinos e Ovinos - Coronel Pacheco, MG \\ ${ }^{2}$ Universidade Federal de Viçosa - Viçosa, MG
}

\begin{abstract}
This study reported the effects of prostaglandin $\left(\mathrm{PGF}_{2 \alpha}\right)$ administration 10 days apart on reproductive parameters of cyclic artificial inseminated (AI) nulliparous Alpine $(n=9)$ and Saanen ( $n=9)$ goats. Animals received two doses of $22.5 \mu \mathrm{g} \mathrm{PGF}_{2 \alpha} 10$ days apart. After $1^{\text {st }}$ and $2^{\text {nd }} \mathrm{PGF}_{2 \alpha}$ administrations, estrus was monitored at $12 \mathrm{~h}$ intervals, with a buck teaser. Plasma progesterone concentration $(\mathrm{ng} / \mathrm{mL})$ was determined from blood sampled on day $0\left(1^{\mathrm{st}} \mathrm{PGF}_{2 \alpha}\right)$ and the following $5,10\left(2^{\frac{\text { nd }}{}} \mathrm{PGF}_{2 \alpha}\right), 15,20,25$ and 30 days. After the onset of the second estrus, females were transrectally ( $5 \mathrm{MHz}$ probe) scanned at 4 hour intervals until at least $8 \mathrm{~h}$ after ovulation. Pregnancy was checked through transrectal ultrasound on days 20, 25, 30, 35 and 90 after insemination. All parameters studied did not differ between breeds $(\mathrm{P}>0.05)$. Estrous response and interval to estrus, respectively, after $1^{\text {st }}(78.9 \%$ and $50.6 \pm 17.2 \mathrm{~h})$ and $2^{\text {nd }}$ $\mathrm{PGF}_{2 \alpha}(88.9 \%$ and $50.0 \pm 14.8 \mathrm{~h})$ administration did not differ $(\mathrm{P}>0.05)$. Overall animals ovulating (100.0\%), interval to ovulation after $2^{\frac{\text { nd }}{-}} \mathrm{PGF}_{2 \alpha}(64.5 \pm 19.5 \mathrm{~h})$ and after estrous onset $(18.0 \pm 9.1 \mathrm{~h})$, ovulation rate $(1.3 \pm 0.5)$, diameter of ovulatory follicle $(8.1 \pm 1.1 \mathrm{~mm})$ were recorded. Embryo loss occurred before day 30 of pregnancy. Estrus can be efficiently synchronized in nulliparous Alpine and Saanen goats with two doses of prostaglandin 10 days apart.
\end{abstract}

Keywords: estrus, ovulation, progesterone, embryo loss, goat

\section{RESUMO}

Relataram-se os efeitos da aplicação de prostaglandina sobre características reprodutivas de cabras leiteiras nulíparas cíclicas. Cabras Alpinas $(n=9)$ e Saanen $(n=9)$ receberam duas doses de $22,5 \mu \mathrm{g}$ $P F_{2 \alpha}$ com 10 dias de intervalo. A progesterona plasmática $(n g / m L)$ foi determinada a partir de amostras de sangue coletadas nos dias 0 (primeira dose), 5, 10 (segunda dose), 15, 20, 25 e 30. Após início do segundo estro, as fêmeas foram monitoradas por ultrassonografia transretal a cada quatro horas até oito horas após a ovulação. A gestação foi verificada por ultrassonografia transretal nos dias 20, 25, 30, 35 e 90 após a segunda dose. As características estudadas foram semelhantes entre as raças $(P>0,05)$. Animais em estro e o intervalo parto-estro de, respectivamente, 78,9\% e 50,6 $\pm 17,2 \mathrm{~h}$ e $88,9 \%$ e $50,0 \pm 14,8$ após a primeira e segunda administrações de prostaglandina, não diferiram $(P>0,05)$. Todas as cabras ovularam e registraram-se valores do intervalo parto-ovulação após a segunda aplicação de

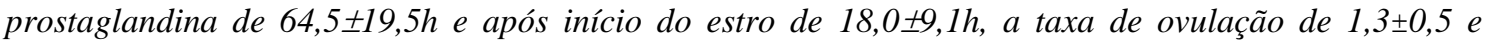
diâmetro do folículo ovulatório de $8,1 \pm 1,1 \mathrm{~mm}$. Perda embrionária ocorreu antes de 30 dias de gestação. $O$ estro pode ser eficientemente sincronizado em cabras leiteiras núliparas com duas doses de prostaglandina intervaladas de 10 dias.

Palavras-chave: caprino, estro, ovulação, progesterona, perda embrionária

Recebido em 13 de julho de 2011

Aceito em 10 de janeiro de 2012

E-mail: jeferson@cnpc.embrapa.br 


\section{INTRODUCTION}

The concentration of herd reproductive activities has a direct impact on breeding management and handling. In this context, estrous synchronization can be a valuable tool, since it allows at any given week day activities such as artificial insemination and embryo transfer, easier estrous identification which facilitates reproductive management as well as allows birth synchronization and thus meat and milk production.

Basically there are three ways to synchronize estrus in goats. First, in anestrous goats by using a combination of progestagens, gonadotrophins and prostaglandins through light programs or melatonin implants. Second, by male effect in females previously isolated (one to three months) from the buck's presence, which may also activate the estrous synchronization cycle as well as anticipate the reproductive activity in anestrous females (transition season). The third form includes prostaglandin administration either in a single dose or in two doses 10 to 11 days apart during breeding season (Fonseca et al., 2007).

An important factor to consider in estrous synchronization and superovulation is the moment of ovulation. Its recognition and association with the interval elapsed from the administration of prostaglandin and onset and duration of estrus may generate more efficient protocols of artificial insemination, based on estrous detection and at a fixed time. The moment of ovulation was initially recognized by laparoscopy (Chemineau, 1983) and nowadays may be easily identified by ultrasound (Castro $e t$ al., 1999). Soon one may monitor ovarian dynamics from the onset of estrus and identify ovulatory follicles and its rupture, and formation of the hemorrhagic body, based on each structure ecographic characteristics. Additionally, the recognition of possible differences between breeds, as well as hormonal profiles during and after synchronization may be very important.

The objective of this study was to evaluate the effects of administering two doses of prostaglandin at 10 days apart on reproductive parameters of nulliparous Alpine and Saanen goats.

\section{MATERIALS AND METHODS}

This study was conducted during the months of May and June in a location with the following coordinates: $20^{\circ} 45^{\prime} \mathrm{S}$ latitude and $42^{\circ} 51^{\prime} \mathrm{WG}$ longitude; altitude of $692.73 \mathrm{~m}$ with CWA (dry winter and humid summer) climate, annual average temperature of $20.9^{\circ} \mathrm{C}$ and annual rainfall of $1,203 \mathrm{~mm}^{3}$. At these coordinates, the transitional portion of the seasonal breeding pattern extends from December to February, the breeding season from March (end of summer) to June (end of autumn) and the anestrous season from July to November.

The experiment used Saanen and Alpine breeds. Nine Alpine (aged 8-18 months and weighting $31.3 \pm 1.9 \mathrm{~kg}$, and nine Saanen, aged 8-18 months and weighting of $37.5 \pm 7.7 \mathrm{~kg}$ goats were used. Body condition score (scale 1 to 5 ) was assessed and showed $2.5 \pm 0.2$ e $3.0 \pm 0.7$, respectively, for Alpine and Saanen goats. Goats were kept on suspended pens and fed ad libitum with corn silage and concentrated ration twice a day according to nutrient demand. Water and mineral salt were permanently available.

Animals received two doses of $22.5 \mu \mathrm{g}$ synthetic prostaglandin (d-cloprostenol; Prolise ${ }^{\circledR}$, ARSA S.R.L., Buenos Aires, Argentina) intra-vulvo submucosal at 10 days interval. After the first prostaglandin administration, estrus was monitored twice daily from 06:00 to 08:00AM and 4:00 to 06:00PM, with the aid of buck teasers. Estrous detection persisted for 10 days until the administration of the second dose of prostaglandin, when all animals were evaluated through transrectal ultrasound with the help of a $5 \mathrm{MHz}$ probe $\left(\right.$ Aloka $^{\circledR}, \mathrm{SSD}-500$, Tokyo, Japan) coupled to polyethylene support. After the administration of the second dose of prostaglandin, doses were observed every four $h$ in order to accurately identify the onset of estrus. Once estrus was identified, animals were submitted to ultrasound evaluation every four $\mathrm{h}$ until ovulation detection and at least for the next 8h. Ovulation was considered as having occurred when previous detected follicles collapsed and could not be observed (Ginther and Kot, 1994). Both ovary and uterus were monitored. After ovulation detection, females were inseminated with frozen-thawed semen $\left(0.25 \mathrm{~mL}\right.$ straws $/ 100 \times 10^{6}$ spermatozoa) of proved fertility with a minimum of $50 \%$ of progressive 
motility after thawing and $40 \%$ HOST reaction (Fonseca et al., 2005). All females were evaluated through ultrasound following an elapsed period of 20, 25, 30, 35 and 90 days after the second prostaglandin administration, in order to prematurely detect and confirm pregnancy.

Blood was sampled on days 0 (first prostaglandin administration), 5, 10 (second prostaglandin administration), 15, 20, 25 and 30 through jugular puncture in heparinized vacuolated tubes. After collection, the tubes were kept on ice until centrifugation in a refrigerated centrifuge at $5^{\circ} \mathrm{C}$, at $2500 \times \mathrm{g} / 15$ min. Plasma was then aspired and stored at $-20^{\circ}$ $\mathrm{C}$ until analysis. Time from blood collection to plasma aspiration did not exceed $2 \mathrm{~h}$. Plasma progesterone concentration (ng/mL) was determined through the use of the solid phase radioimmunoassay, using a commercial kit (Coat-a-count ${ }^{\circledR}$ progesterone kit, DPC, Diagnostic Products Co., Los Angeles, CA, USA). The mean intra- and inter-assay coefficient of variation was $7 \%$ and $8 \%$, respectively.

The following characteristics were determined: estrous response; interval to estrus (h): time from prostaglandin administration to the onset of estrus; interval to ovulation (h): time from second prostaglandin administration to ovulation; interval to ovulation after estrous onset (h): time from estrous onset to ovulation; interval to artificial insemination (AI; h): time from second prostaglandin administration to $\mathrm{AI}$; interval to $\mathrm{AI}$ after estrous onset (h): time from estrous onset after second prostaglandin administration to AI; percentage (\%) of ovulating animals; ovulation rate; diameter of ovulatory follicle ( $\mathrm{mm})$ : maximum diameter of follicle previously detected before ovulation; ovulation on left or right ovary $(\%)$; plasma progesterone concentration $(\mathrm{ng} / \mathrm{mL})$; number of fetuses per goat artificially inseminated; conception rate $(\%)$.

Statistical analysis included one way analysis of variance for testing the differences in variables studied between nulliparous Alpine and Saanen goats. Parametric variables were tested with the aid of Tukey test processed with SAEG. Nonparametric variables were analyzed using $\chi^{2}$ procedures. Linear Pearson correlation was performed (Ribeiro Júnior, 2001). All tests were considered at minimum level of $5 \%$ significance.

\section{RESULTS}

The percentage of animals in estrus after the first and the second prostaglandin administrations did not differ between breeds $(\mathrm{P}>0.05$; Table 1$)$. Two responsive goats showing estrus 36 and $48 \mathrm{~h}$ after first dose (one Alpine and one Saanen) displayed another estrus five days after this one. These animals did not present estrus after second prostaglandin administration.

Table 1. Estrous response (\%) of Alpine and Saanen goats submitted to administration of two doses of cloprostenol 10 days apart

\begin{tabular}{lcc}
\hline Breed & First prostaglandin & Second prostaglandin \\
\hline Alpine & $88.9 \%(8 / 9)$ & $88.9 \%(8 / 9)$ \\
Saanen & $66.7 \%(6 / 9)$ & $88.9 \%(8 / 9)$ \\
Total & $77.8 \%(14 / 18)$ & $88.9 \%(16 / 18)$ \\
\hline
\end{tabular}

The interval to estrus and time to artificial insemination relative to these times are reported in Table 2. Negative correlation was observed between interval to estrus after first prostaglandin administration $(\mathrm{r}=-0.55 ; \mathrm{P}<0.05)$ and interval to estrus after second prostaglandin administration.

Four goats showed P4 concentration inferior to $1 \mathrm{ng} / \mathrm{mL}$ on day 0 ; three did not come into estrus and one came into estrus $14 \mathrm{~h}$ after first cloprostenol administration. These four goats showed lower $(\mathrm{P}<0.05)$ P4 $(0.3 \pm 0.3 \mathrm{ng} / \mathrm{mL})$ at first cloprostenol administration when compared with those which came into estrus $(5.6 \pm 2.3 \mathrm{ng} / \mathrm{mL})$. A similar pattern was observed for the second cloprostenol administration, when three goats with $\mathrm{P} 4$ lower than $1 \mathrm{ng} / \mathrm{mL}$ did not come into estrus. These three goats showed lower $(\mathrm{P}<0.05)$ P4 $(0.3 \pm 0.3 \mathrm{ng} / \mathrm{mL})$ at second cloprostenol administration when compared with those that came into estrus $(5.8 \pm 2.2 \mathrm{ng} / \mathrm{mL})$ (Figure 1$)$. On the other hand, goats that did not come into estrus after first or second cloprostenol administration showed higher $(\mathrm{P}<0.05) \mathrm{P} 4$ on days 5 and 15 $(4.6 \pm 2.1$ and $4.8 \pm 0.6 \mathrm{ng} / \mathrm{mL})$ than those showing estrus $(0.8 \pm 0.6$ and $1.0 \pm 1.9 \mathrm{ng} / \mathrm{mL})$, respectively. 
Table 2. Reproductive characteristics (hours) after first and second dose of prostaglandin $\left(\mathrm{PGF}_{2 \alpha}\right)$ administered 10 days apart in nulliparous Alpine and Saanen goats (mean \pm SD)

\begin{tabular}{lccc}
\hline Characteristic & Alpine & Saanen & Total \\
\hline Interval to estrus after $1^{1 \text { st }} \mathrm{PGF}_{2 \alpha}$ & $49.5 \pm 20.2$ & $52.0 \pm 14.2$ & $50.6 \pm 17.2$ \\
& $(\mathrm{n}=8)$ & $(\mathrm{n}=6)$ & $(\mathrm{n}=14)$ \\
Interval to estrus after $2^{\text {nd }} \mathrm{PGF}_{2 \alpha}$ & $49.5 \pm 16.8$ & $50.5 \pm 13.8$ & $50.0 \pm 14.8$ \\
& $(\mathrm{n}=8)$ & $(\mathrm{n}=8)$ & $(\mathrm{n}=16)$ \\
& $66.7 \pm 17.9$ & $62.2 \pm 21.9$ & $64.5 \pm 19.5$ \\
Interval to ovulation after $2^{\mathrm{nd}} \mathrm{PGF}_{2 \alpha}$ & $(\mathrm{n}=8)$ & $(\mathrm{n}=8)$ & $(\mathrm{n}=16)$ \\
& $19.2 \pm 8.6$ & $16.7 \pm 10.0$ & $18.0 \pm 9.1$ \\
& $(8)$ & $(\mathrm{n}=8)$ & $(\mathrm{n}=16)$ \\
Interval to ovulation after estrous onset & $21.2 \pm 8.6$ & $18.7 \pm 10.0$ & $20.0 \pm 9.1$ \\
& $(8)$ & $(8)$ & $(\mathrm{n}=16)$ \\
Interval from estrous onset to AI & $68.7 \pm 17.9$ & $64.2 \pm 21.9$ & $66.5 \pm 19.5$ \\
& $(\mathrm{n}=8)$ & $(\mathrm{n}=8)$ & $(\mathrm{n}=16)$ \\
Interval from $2^{\mathrm{nd}} \mathrm{PGF}_{2 \alpha}$ to $\mathrm{AI}$ & & &
\end{tabular}

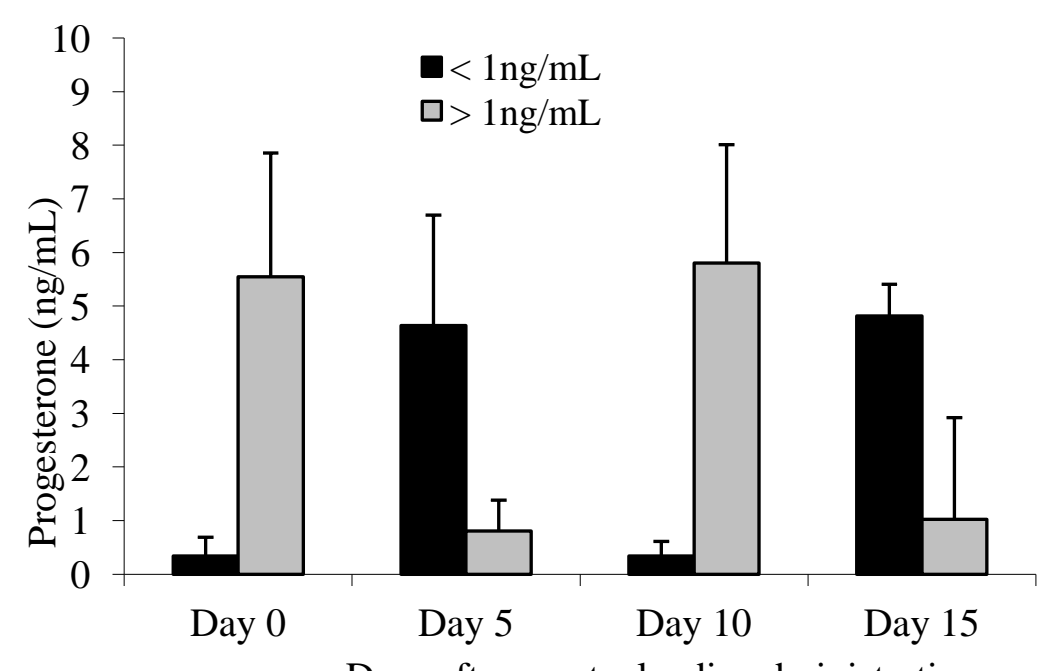

Days after prostaglandin administration

Figure 1. Nulliparous dairy goats submitted to estrous synchronization with two doses of $22.5 \mu \mathrm{g}$ cloprostenol (PGF2 $\alpha$ ) on days 0 and 10 that showed plasma progesterone concentration (ng/mL) lower or higher to $1 \mathrm{ng} / \mathrm{mL}$ on the moment of the cloprostenol administration.

Ovulatory characteristic of estrous synchronized goats submitted to ultrasonography evaluation are shown in Table 3.

Negative correlation was observed between interval to estrus after the first prostaglandin administration and interval to ovulation after the second prostaglandin administration $(\mathrm{r}=-0.57$; $\mathrm{P}<0.05$ ). One Alpine goat was removed from the experiment during ultrasound evaluation because of accidental natural breeding.

In both breeds embryo loss occurred before ultrasonography on the $30^{\text {th }}$ day. Ultrasonography performed on day 20 of the studied animals (17 to 18 days after ovulation) was $94.7 \%$ efficient in order to detect pregnancy precociously (vesicles). Only one goat which showed higher progesterone $(11.6 \mathrm{ng} / \mathrm{mL})$ on day 20 was not classified as pregnant through the same day ultrasound. However, this goat came into estrus five days later (day 25). One Alpine goat with $1.5 \mathrm{ng} / \mathrm{mL}$ P4 on day 20 was pregnant at ultrasonography, but this goat came into estrus four days before day 20. For the other animals, those with progesterone under $0.5 \mathrm{ng} / \mathrm{mL}$ $(0.2 \pm 0.1 \mathrm{ng} / \mathrm{mL}$; range 0.1 to $0.4 \mathrm{ng} / \mathrm{mL})$ or higher than $1 \mathrm{ng} / \mathrm{mL} \quad(7.1 \pm 0.5 \mathrm{ng} / \mathrm{mL}$; range 2.8 to $8.9 \mathrm{ng} / \mathrm{mL}$ ) were classified as non-pregnant and pregnant, respectively, through ultrasonography on the $20^{\text {th }}$ day. 
Effects of prostaglandin...

Table 3. Ultrasonography characteristics of ovarian follicles after the second prostaglandin administration in nulliparous Alpine and Saanen goats submitted to two doses of prostaglandin 10 days apart

\begin{tabular}{lccc}
\hline Parameter & Alpine & Saanen & Total \\
\hline Number of animals & 8 & 8 & 16 \\
Ovulation in right ovary $(\%)$ & $7(63.6 \%)$ & $7(70.0 \%)$ & $14(66.7 \%)$ \\
Ovulation in left ovary $(\%)$ & $4(36.4 \%)$ & $3(30.0 \%)$ & $7(33.3 \%)$ \\
Goats that ovulated $(\%)$ & $8(100.0 \%)$ & $8(100.0 \%)$ & $16(100.0 \%)$ \\
Ovulation rate & $1.37 \pm 0.5$ & $1.25 \pm 0.5$ & $1.31 \pm 0.5$ \\
Diameter of ovulatory follicles $(\mathrm{mm})$ & $8.2 \pm 1.2$ & $8.0 \pm 1.1$ & $8.1 \pm 1.1$ \\
\hline
\end{tabular}

$\mathrm{P} 4$ did not differ $(\mathrm{P}>0.05)$ between Alpine and Saanen goats during days studied (Figure 2). Vesicles counts recorded 1.6 and 1.0 for Alpine and Saanen goats, respectively at day 20 after the second cloprostenol administration. From four Alpine goats with two vesicles at this time, two remained with both vesicles, one lost one vesicle, and one lost both vesicles. From seven goats with one vesicle, two Alpine and three Saanen goats lost their vesicles until the end of the study.

Goats were grouped as pregnant (vesicles present) and non-pregnant (vesicles absent) at day 20 after the second prostaglandin administration. $\mathrm{P} 4$ was higher $(\mathrm{P}<0.01)$ in pregnant than in non-pregnant at this time (Figure 3).

Embryo detection and loss are presented in Figure 4. The number of pregnant animals detected via ultrasound 20 days after the administration of the second dose of prostaglandin ( $\cong$ day 18 after ovulation) was $7 / 8$ $(77.8 \%)$ in the Alpine and $5 / 8(62.5 \%)$ in the Saanen breed.

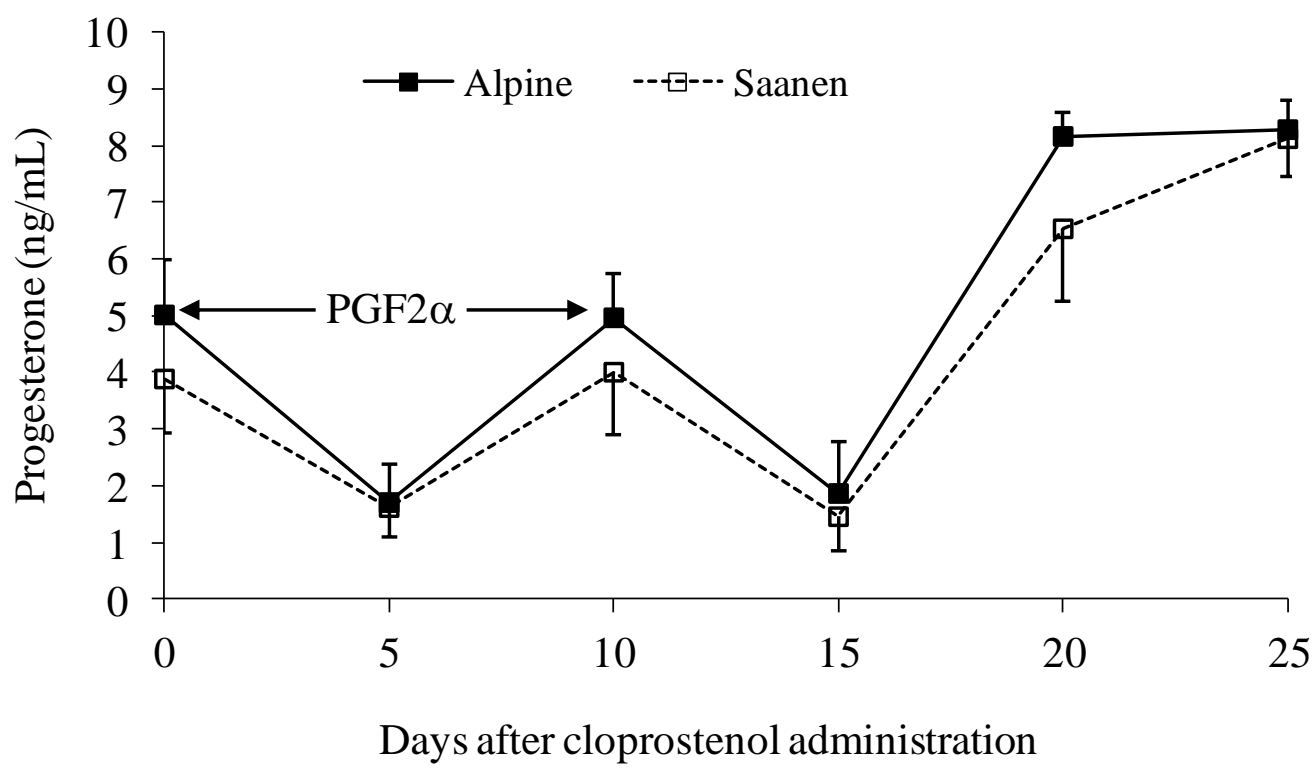

Figure 2. Plasma progesterone concentration (ng/mL) of nulliparous Alpine and Saanen goats submitted to estrous synchronization with two doses of $22.5 \mu \mathrm{g}$ cloprostenol (PGF2 $\alpha$ ) 10 days apart. 


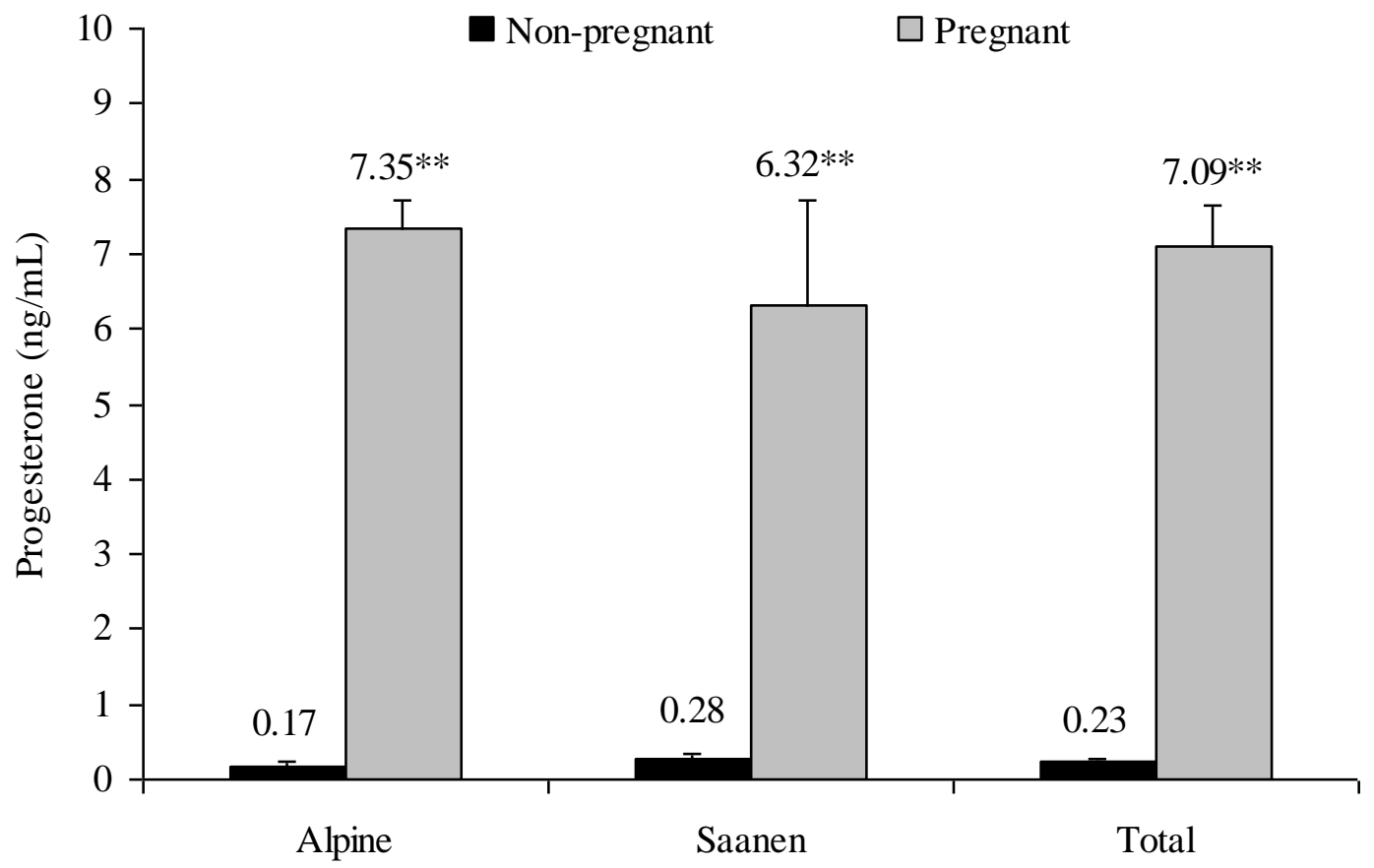

Figure 3. Plasma progesterone concentration $(\mathrm{ng} / \mathrm{mL})$ of artificial inseminated nulliparous Alpine and Saanen goats with apparent pregnant uterus detected by ultrassonography at day 20 after second cloprostenol administration. $* * \mathrm{P}<0.01$.

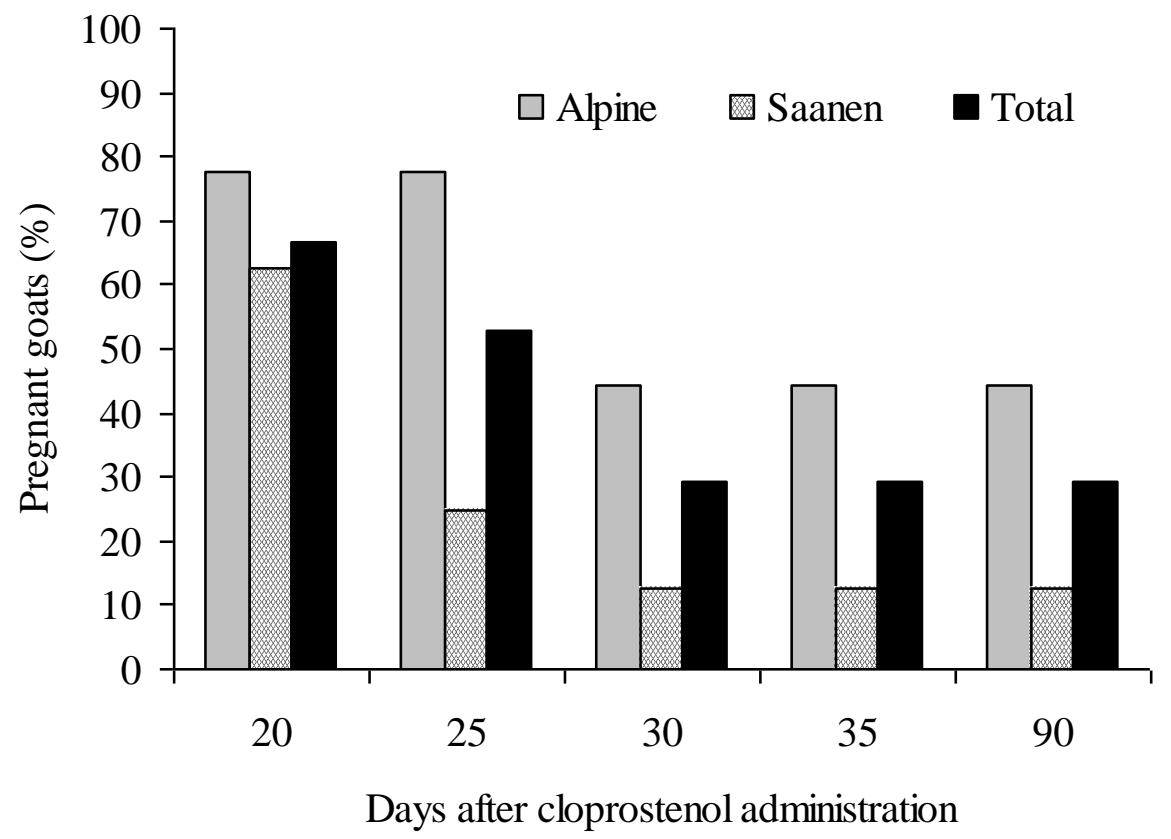

Figure 4. Pregnancy rate (\%) of artificial inseminated nulliparous Alpine and Saanen goats checked via ultrassonography from days 20 to 90 after the second cloprostenol administration. 
In both breeds embryo loss occurred before ultrasonography on the $30^{\text {th }}$ day. Ultrasonography performed on day 20 of the studied animals (17 to 18 days after ovulation) was $94.7 \%$ efficient in order to detect pregnancy precociously (vesicles). Only one goat which showed higher progesterone $(11.6 \mathrm{ng} / \mathrm{mL})$ on day 20 was not classified as pregnant through the same day ultrasound. However, this goat came into estrus five days later (day 25). One Alpine goat with $1.5 \mathrm{ng} / \mathrm{mL} \mathrm{P} 4$ on day 20 was pregnant at ultrasonography, but this goat came into estrus four days before day 20. For the other animals, those with progesterone under $0.5 \mathrm{ng} / \mathrm{mL}$ $(0.2 \pm 0.1 \mathrm{ng} / \mathrm{mL}$; range 0.1 to $0.4 \mathrm{ng} / \mathrm{mL})$ or higher than $1 \mathrm{ng} / \mathrm{mL} \quad(7.1 \pm 0.5 \mathrm{ng} / \mathrm{mL}$; range 2.8 to $8.9 \mathrm{ng} / \mathrm{mL}$ ) were classified as non-pregnant and pregnant, respectively, through ultrasonography on the $20^{\text {th }}$ day.

As can be seen on Fig. 4, the ultrasonography revealed that embryonic losses occurred before the first 30 days of pregnancy. Under the conditions of this study, embryos/fetuses that survived up to this time were not lost until 90 days of pregnancy.

\section{DISCUSSION}

The percentage of animals in estrus after the first cloprostenol administration was similar to those related by Goel and Agrawal (1998), who reported $81.8 \%$ estrous response in goats without definite breed and $75.0 \%$ in Jakhrana lactating goats. At that moment, forming corpus luteum was not susceptible to prostaglandin effects. Thus, short estrous cycle can decrease the estrous response after the second prostaglandin administration.

Furthermore, the percentage of animals in estrus after the second administration of prostaglandin was similar to the one described by Pandey et al. (1985) in cyclic Black Bengal goats (86.0\%). The same dose and intervals used in the present study were also studied by Siqueira et al. (2009) in Toggenburg goats who reported 100\% estrous response after second prostaglandin administration. Previous studies reported dosages ranging from 50 to $250 \mu \mathrm{g}$ of the same drug (Baril et al., 1993; Kusima et al., 2000).

Overall, the interval to estrus observed in this study after first (50.1h) and second (50.0h) prostaglandin administration was smaller than those (71.3 and 65.3h) reported by Goel and Agrawal (1998), respectively in Jakhrana and unknown origin goats. The smaller interval related in this study as compared to that could be a result of administration route. Mellado et al. (1994) reported a smaller interval from prostaglandin administration to the onset of estrus by comparing the use of intra-vulvo submucosal to the results of intramuscular route. Thus, it appears that the intra-vulvo submucosal route could allow a quicker access and a greater quantity of molecules to the target tissue, the corpus luteum, averting a first passage and hepatic metabolization. Siqueira et al. (2009) reported a $46 \mathrm{~h}$ interval to estrus after second prostaglandin administration in Toggenburg goats using the same via. In Nubian goats submitted to two prostaglandin administrations 12 days apart, Romano (1998) reported interval to estrus higher after first (72h) and similar after the second prostaglandin administration (52h) than those reported in the present study.

Goat experiencing estrus later after first prostaglandin administration could probably be in growing follicular pattern and have follicles capable of ovulating if luteal progesterone was removed. This model was proposed by Menchaca and Rubianes (2004). Thus, according to interval between prostaglandins, one or two follicular waves can emerge in this period. If luteolysis is evoked during the follicular wave's final growing phase, animals come into estrus and ovulate earlier than those animals which luteolysis occurred at the initial rump of follicles growing.

As shown in Figure 1, the presence of an active corpus luteum at the time of the prostaglandin administration is the key point to determine the success of estrous synchronization. Animals with P4 shorter than $1 \mathrm{ng} / \mathrm{mL}$ at this time could have been in estrus two or three days earlier, or entering in estrus at the moment of the prostaglandin administration. Consequently, at day five pos prostaglandin administration, these animals are expected to have higher P4 when compared to those that suffer luteolysis and came into estrus in response to prostaglandin.

Menchaca et al. (2007) working with cyclic pluriparous Alpine goats submitted to estrous 
synchronization with short-term progesterone protocol (five days) without eCG administration reported $100 \%$ goats ovulating, 1.5 ovulation per goat and $9.9 \mathrm{~mm}$ diameter of ovulatory follicles. Maffili et al. (2006), with protocol similar to a previous study but with eCG administered at sponge or CIDR removal, reported $100 \%$ goats ovulating, 1.5 ovulation per goat and $7.7 \mathrm{~mm}$ diameter of ovulatory follicles in Toggenburg goats.

The higher ovulation frequency of the right ovary noted in this study corroborates the conclusion of Prasad et al. (1980). Camp et al. (1983) also noticed that the right ovary is more active than the left one. Chávez et al. (1987) noted this phenomenon in rats when they showed the asymmetry of the information carried between right and left vagal nerve to ovaries. The uni or bilateral section of the vagal nerve produced different results depending on the in situ ovary. Ovulation rate in rats unilaterally ovariectomized was smaller in the left ovary when compared to the right one (42 vs. 84\%). The authors concluded that, in the model used, regulatory compensatory systems are more likely to occur in the right ovary than in the left one. On the other hand, Romano and Abella (1997) did not find activity differences between the right and left ovaries in Nubian goats.

Higher P4 in pregnant goats 30 days after the second administration of prostaglandin was expected because non-pregnant animals could have had or were close to having luteolysis, as shown by Regueiro et al. (1999). The presence of functional corpus luteum in the moment of prostaglandin administration is required to successfully synchronize estrus. This corpus luteum must be responsive to prostaglandin activity, which happens on the fourth day of the estrous cycle in goats (Ott et al., 1980).

Pregnant animals detected via ultrasound 20 days after the administration of the second dose of

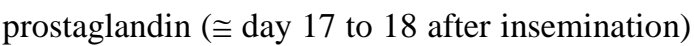
were confirmed by their P4. This proves the strong association between ultrasound and hormonal diagnostic exams, as noted by Engeland et al. (1997) when they studied 50 day pregnant goats. Using $5 \mathrm{MHz}$ transrectal probe, Martinez et al. (1998) also commented on the presence of small vesicles in non-pregnant animal's uterine lumen. They also reported that the first evidences of the presence of concepts were detected on day 15 and cardiac pulse on day 19. The present study confirms the possibility of precocious identification of goat pregnancy. The possibility of hormonal dosage strengthens this diagnosis.

It was previously reported that although confirmed pregnant and giving birth according to first estrus, an Alpine goat showed a second estrus 15 days after the first one (Fonseca et al., 2006). Thus this kind of finding appears to be repetitive for goats.

The results of this study confirm the possibility of precocious identification of goat pregnancy (<20 days). However, given embryonic mortality, it is suggested that a later evaluation (after 30 days) should be made to confirm pregnancy. Thus, there is no practical use for earlier detection of pregnancy in goats.

Finally, the central objectives of this study were to test the efficiency of estrous synchronization with prostaglandins and the identification of the ovulation moment. Due to this, goats were inseminated after ovulation, and the quality and viability of the formed embryo could be compromised. In cattle, Saacke et al. (2000) noted that insemination at the moment of estrous detection lead to better quality embryos but with a smaller fertilization rate. Inseminations performed $24 \mathrm{~h}$ after the onset of estrus resulted in higher fertilization rates but also increased the amount of embryos with inferior quality and degenerated ones. Inseminations performed $12 \mathrm{~h}$ after the onset of estrus resulted in intermediary results. Additionally, Motlomelo et al. (2002) observed a $52 \%$ pregnancy rate in progestagen induced estrous goats. They inferred that the probable explanation of the relatively small pregnancy rate was a consequence of insemination at the end of the estrus.

\section{CONCLUSIONS}

Estrus can be efficiently synchronized in Alpine and Saanen breeds using two doses of prostaglandin 10 days apart. The identification of the ovulation relative to the estrous onset is very important to establish effective protocols of insemination. Ultrasound supervision associated with plasma hormone (progesterone) determination is an important study tool. 
Embryos may be visualized and their development may easily be followed. However, precocious diagnosis should be confirmed in more advanced pregnancy stages given the possibility of embryonic losses occurring after that.

\section{ACKNOWLEDGEMENTS}

Authors thank Professor Marcelo Teixeira Rodrigues (Federal University of Viçosa) for providing animals, animal feeding and housing for the conduction of this study, and the National Council for Scientific and Technological Development (CNPq; Project 559151 / 2010-1) for financial support.

\section{REFERENCES}

BARIL, G.; LEBOEUF, B.; SAUMANDE, J. Synchronization of estrus in goats: the relationship between time of occurrence of estrus and fertility following artificial insemination. Theriogenology, v.49, p.621-628, 1993.

CAMP, J.C.; WILDT, D.E.; HOWARD, P.K. et al. Ovarian activity during normal and abnormal length estrous cycles in the goat. Biol. Reprod., v.28, p.673-681, 1983.

CASTRO, T.; RUBIANES, E.; MENCHACA, A. et al. Ovarian dynamics, serum estradiol and progesterone concentrations during the interovulatory interval in goats. Theriogenology, v.52, p.399-411, 1999.

CHÁVEZ, R.; CRUZ, M.E.; DOMÍNGHES, R.Differences in the ovulation rate of right or left ovary in unilaterally ovariectomized rats: effect of ipsi- and contralateral vagus nerves on the remaining ovary. J. Endocrinol., v.113, p.397401, 1987.

CHEMINEAU, P. Effect on oestrus and ovulation of exposing Creole goats to the male at three times of the year. J. Reprod. Fertil., v.67, p.65-72, 1983.

ENGELAND, I.V.; ROPSTAD, E.; ANDRESEN, O.; EIK, L.O. Pregnancy diagnosis in dairy goats using progesterone assay kits and oestrous observation. Anim. Reprod. Sci., v.4, p.237-243, 1987.

FONSECA, J.F.; MAFFILI, V.V.; RODRIGUES, M.T. et al. Effects of hCG on progesterone concentrations and fertility in cyclic, lactating Alpine goats. Anim. Reprod., v.3, p.410-414, 2006.

FONSECA, J.F.; SOUZA, J.M.G.; BRUSCHI, J.H. Sincronização de estro e superovulação em ovinos e caprinos. In: SIMPÓSIO DE CAPRINOS E OVINOS DA EV-UFMG, 2., 2007, Belo Horizonte. Anais ... Belo Horizonte: CENEx - EV/UFMG, 2007. p.167-195

FONSECA, J.F.; TORRES, C.A.A.; MAFFILI, V.V. et al. The hypoosmotic swelling test in fresh goat spermatozoa. Anim. Reprod., v. 2, p. 139-144, 2005.

GINTHER, O.J.; KOT, K. Follicular dynamics during the ovulatory season in goats. Theriogenology, v.42, p.987-1001, 1994.

GOEL, A.K.; AGRAWAL, K.P. Oestrus synchronization in cyclic goats following lutalyse administration. In. J. Anim. Sci., v.68, p.155-156, 1998.

KUSIMA, N.T.; TARWIREI, F.; HAMUDIKUWANDA, H. et al. A comparison of the effects of progesterone sponges and ear implants, PGF, and their combination on efficacy of estrus synchronization and fertility of Mashona goat does. Theriogenology, v.53, p.1567-1580, 2000.

MAFFILI, V.V. ; TORRES, C. A. A. ; BRUSCHI, J.H. et al. Indução de estro em cabras da raça Toggenburg com dois diferentes dispositivos intravaginais. Arq. Bras. Med. Vet. Zootec., v.58, p.367-372, 2006.

MARTINEZ, M.F.; BOSCH, P.; BOSCH, R.A. Determination of early pregnancy and embryonic growth in goats by transrectal ultrasound scanning. Theriogenology, v.49, p.1555-1565, 1998.

MELLADO, M.; ALEMÁN, R.; OROZCO, F.J.; URIBE, G. Effect of prostaglandin F2 $\alpha$ dosage and route of administration on estrus response in Criollo goats under range conditions. Small Rumin. Res., v.14, p.205-208, 1994.

MENCHACA, A.; RUBIANES, E. New treatments associated with timed artificial insemination in small ruminants. Reprod. Fertil. Devel., v.16, p.403-413, 2004.

MENCHACA, A.; MILLERA, V.; SALVERAGLIO, V.; RUBIANES, E. Endocrine, luteal and follicular responses after 
the use of the Short-Term Protocol to synchronize ovulation in goats. Anim. Reprod. Sci., v.102, p.76-87, 2007.

MOTLOMELO, K.C.; GREYLING， J.P.C.; SCHWALBACH, L.M.J. Synchronization of oestrus in goats: the use of different progestagen treatments. Small Rumin. Res., v.45, p.45-49, 2002.

OTT, R.S.; NELSON, D.R.; HIXO, J.E. Peripheral serum progesterone and luteinizing hormone concentrations of goats during synchronization of estrus and ovulation with prostaglandin F2 $\alpha$. Am. J. Vet. Res., v.41, p.1432-1434, 1980.

PANDEY, J.N.; ISHWAR, A.K.; SINGH, R.A. Oestrous synchronization in goats using prostaglandin (Lutalyse). In. J. Anim. Sci., v.55, p.551-552, 1985.

PRASAD, S.P.; DAS, S.C.; BHATTACHARYYA, N.K. A study on the characteristics of Graafian follicles and ovulation sequence in nulliparous Barbari nannies. Int. J. Anim. Sci., v.50, p.53-57, 1980.

REGUEIRO, M.; CLARIGET, R.P.; GANZÁBAL, A. Effect of medroxyprogesterone acetate and $\mathrm{eCG}$ treatment on the reproductive performance of dairy goats. Small Rumin. Res., v.33, p.223-230, 1999.

RIBEIRO JÚNIOR, I. Análises estatísticas no SAEG. Viçosa: Editora UFV, 2001, 301p.

ROMANO, J.E.; Effect of two doses of cloprostenol in two chemes for estrous synchronization in Nubian goats. Small Rumin. Res., v.28, p.171-176, 1998.

ROMANO, J.E.; ABELLA, D.F. Effect of service on duration of oestrus and ovulation in dairy goats. Anim. Reprod. Sci., v.47, p.107-112, 1997.

SAACKE, R.G.; DALTON, J.C.; NADIR, S. et al.Relationship of seminal traits and insemination time to fertilization rate and embryo quality. Anim. Reprod. Sci., v.60-61, p.663-677, 2000.

SIQUEIRA, A. P. ; FONSECA, J.F. SILVA FILHO, J. M. Parâmetros reprodutivos de cabras Toggenburg inseminadas com sêmen resfriado, após diluição em meio à base de gema de ovo. Arq. Bras. Med. Vet. Zootec., v.61 299-305, 2009. 